\title{
Corporate Governance Application, Audit Quality and Audit Report Lag: The Moderating Role of Law Compliance
}

\author{
Yenny Dwi Handayani ${ }^{1} \&$ Ewing Yuvisa Ibrani ${ }^{2}$ \\ ${ }^{1}$ Business and Economic Faculty, Mercu Buana University, Indonesia \\ ${ }^{2}$ Business and Economic Faculty, Sultan Ageng Tirtayasa University, Indonesia \\ Correspondence: Yenny Dwi Handayani, Business and Economic Faculty, Mercu Buana University, Indonesia.
}

Received: June 16, 2019

doi:10.5430/ijfr.v10n4p164
Accepted: July 17, 2019

Online Published: July 23, 2019

URL: https://doi.org/10.5430/ijfr.v10n4p164

\begin{abstract}
This study aims to examine the effect of corporate governance application and audit quality on audit report lag. Special attention is paid to investigate the moderating role of law compliance in the relationships. 180 manufacturing companies are observed during the three years of observation (2013-2015). Data are analyzed using moderated regression analysis (MRA). The results show that corporate governance application and audit quality have no effect on audit report lag. While law compliance moderates the relationship between corporate governance application and audit report lag.
\end{abstract}

Keywords: corporate governance application, audit quality, audit report lag, law compliance

\section{Introduction}

The results of company's management performance are reflected in the financial statements. The financial statements presented should be easy to understand, relevant, reliable and comparable. There are several obstacles to producing relevant financial statements. One of them is the timeliness in submitting financial statements that will later be published. Timeliness is a key characteristic of financial statements (IAI, 2014). Under the regulation of the financial services authority No. 2/POJK.04/2015 concerning the obligation to submit financial statements that a public company is required to submit an annual report to the financial services authority no later than 4 (four) months after the closing of the book. In addition, there are other parties who need timely submission of financial statements, such as investors. Investors need information about the company's financial condition, which will later be used as material to make decisions about investor relations with the company (Nurlis, 2014).

The financial services authority regulations make management have to submit financial reports in a timely manner, where the timeliness of submitting these financial statements is inseparable from the audit process carried out by the office of the public accountant. Based on work standards, the professional standards of public accountants state that work must be planned as well as possible (IAPI, 2011). The auditing standard emphasizes that the auditor has to consider and implement planning procedures including the preparation of audit program and gathering information about the business, which really takes a long time. Management must consider the relative benefits of timely financial reporting with the reliability of the contents of financial statements.

The length of time of financial statement is presented until the date of the issuance of an audited financial report is called an audit report lag (Habib \& Bhuiyan, 2011). The longer the audit report lag in auditing shows the longer the auditor completes the audit work so that it will later affect the length of the issuance of financial statements. If the publication of audited financial statements is late, these financial statements will lose their relevance value. The auditor must be able to estimate the time of completion of the audit process so that the publication of financial statements can be timely. To suppress the delay in the submission of financial statements, it is necessary to have a corporate governance mechanism within the company. This supervision is very necessary so that the submission of financial reports can be timely.

One component of corporate governance is the audit committee, which has an important role in the process of preparing financial statements, namely reviewing the financial information that will be issued by the issuer (Wijaya, 2012). Kirk (2000) in Naimi (2010) states that the contribution of the audit committee in the company is when reviewing and providing objective reviews of financial statements, there is an increase in the quality of financial 
reporting. The independent audit committee is expected to be able to reduce the audit lag that occurs within the company. Research conducted by Lailah (2016) states that audit committees do not affect audit report lag. This is related to the competence of the audit committee and it is not enough to provide a significant role in financial reporting.

Timeliness in submitting financial statements cannot be separated from the role of an independent auditor who conducts an audit of the company's financial statements (Rustiarini et al., 2013). Audit quality plays an important role in reducing the delay in publishing company financial statements. The better the audit quality provided by the external auditor will accelerate the publication of the company's financial statements. Companies need auditor services that have knowledge and experience in certain areas of the company. Auditors who often audit the same company will have a better level of knowledge about the client company. Auditors of corporate specialization are also seen as being able to reduce audit reports on client companies because they have better expertise and experience in auditing companies. Habib and Bhuiyan (2011) found that the auditor's knowledge of the company's specialization with clients can improve audit risk assessment and can help auditors anticipate material misstatements. Therefore, this study aims to examine the effect of corporate governance application and audit quality on audit report lag. Special attention is paid to investigate the moderating role of law compliance in the relationships.

\section{Literature Review and Hypotheses Development}

\subsection{Agency Theory}

Agency theory confirms that the relationship between agents and principals, where one party has more information than others (Jensen \& Meckling, 1979). This agency theory states that the imbalance of information possessed by one party regarding the authority and responsibility held will be used as a tool to maximize profits. Agents have more information about the company than the principal, so that information asymmetry will arise regarding the ownership of information that is not balanced. Many literature uses agency theory (for example, Fama, 1980, Deutsch, 2005, Deutsch, et al., 2011) argues that managers avoid risk more than shareholders because, unlike shareholders who diversify their financial capital, managers cannot diversify their human capital. Therefore, risk avoidance managers are more likely to take a low level of risk thereby reducing shareholder value. Conversely, by aligning managerial interests with the interests of shareholders, strong governance will encourage risk avoidance managers to take higher risks, leading to higher shareholder value.

\subsection{Board of Commissioners Effectiveness and Audit Report Lag}

The rules of the financial services authority No. 33/PJOK.04/2014 state that members of directors board are jointly and severally responsible for the loss of public company for the mistakes or omissions in carrying out their duties. Minnick et al. (2010) noted that the small number of directors would make it easier to carry out coordination activities, whereas the large number would lead to ineffectiveness in the supervisory function. Supervision of the board of commissioners is needed to ensure that the standards of corporate governance are well implemented to accelerate audit report lag in the company. Thus,

\section{H1: Board of commissioners effectiveness affects audit report lag}

\subsection{Audit Committee Effectiveness and Audit Report Lag}

Financial services authority regulation No.55/POJK.04/2015 concerning the establishment and work guidelines of the audit committee and Jakarta stock exchange regulation No. Kep-305/BEJ/07-2004 require the number of audit committee members to be at least 3 (three) people chaired by one independent commissioner and 2 (two) people from outside the independent company. Based on the regulation, it was stated that the audit committee had the task of assisting the board of commissioners in ensuring internal audits. An independent audit is carried out in accordance with the applicable auditing standards so that one of its members must have financial competence.

In order to carry out their duties properly in supervising management performance, the independence of audit committee members is needed so that opportunistic behavior of management can be suppressed and it can be ascertained that financial reports are presented quality (Agoglia et al., 2011). Therefore,

H2: Audit committee effectiveness affects audit report lag

\subsection{Audit Quality and Audit Report Lag}

Professional standards of public accountants (2011) require auditors to have the knowledge used to design audit programs. Auditors who are concentrated in certain industries have a better knowledge of auditing client companies. Deeper knowledge about an industry owned by auditor will result in better audit quality. The results of De Angelo's study (1981) state that financial reporting quality will increase if audits are carried out by industry specialist auditors. One of the competencies possessed by industry specialist auditors is the ability to detect errors to improve efficiency 
and knowledge of financial statement honesty (Herusetya, 2009). Research conducted by Habib and Bhuiyan (2010) found that if the company is audited by industry specialist auditors, audit report lag will be faster than non-industry specialist auditors. Thus,

H3: Audit quality affects audit report lag

\subsection{Law Compliance, Board of Commissioners and Audit Committee Effectiveness on Audit Report Lag}

The rules of the financial services authority (2015) regarding the deadline for submitting audited financial reports have raised concerns for many companies related to the impact if the company is late in submitting audited financial statements. The threat of fines and damage to the company's reputation is the main reasons that companies must deliver audited financial statements on time (Lailah, 2016). The research conducted by Lailah (2016) found that the relationship between board of commissioners and audit report lag is significantly positive. This means that the more the number of board of commissioners in the company, the longer the audit report lag. However, the relationship between these variables is weakened by law compliance, where the board of commissioners will extend audit report lag but can be reduced by law compliance. Therefore,

H4: Law compliance strengthens the relationship between board of commissioner's effectiveness and audit report lag

H5: Law compliance strengthens the relationship between audit committee effectiveness and audit report lag

\section{Research Methods}

The population of this study is manufacturing companies listed on the Indonesia stock exchange with the observation period of 2013-2015. The sample is 148 companies. The sampling technique is done by purposive sampling which is determined based on the following criteria:

1. The company publishes annual financial reports for the period 31 December 2013-2015.

2. The company includes annual reports and financial reports that have been audited by an independent auditor.

3. The company experiences positive profits in the financial statements.

4. The company uses the rupiah currency in the financial statements.

\subsection{Measurement}

1. Audit report lag is calculated from the number of the closing date of the financial report book to the date of audit report issuance.

2. Board of commissioner's effectiveness is measured using 17 questions developed by Ancella (2009).

3. Audit committee effectiveness is measured based on the measurement list developed by Ancella (2009) in Deborah (2012). The total list of measurements is 11 questions grouped into 3 categories include audit committee activities, audit committee size, and audit committee expertise competence.

4. Audit quality is an opportunity for auditors to find and report violations in the client's accounting system (De Angelo, 1981). Industry specialist auditor is used to measure audit quality. This variable is measured using a dummy. Industrial specialty auditor is coded 1 , while non-industry specialist is coded 0 .

5. Law compliance is measured using a ratio. If it is not on time it will be given a value of 1 and if on time it will be given a value of 2 .

6. Company size is a measurement that is grouped based on the size of the company and can describe the company activities (Nugraha \& Meiranto, 2015). The formula used to calculate company size according to Hadi and Mangoting (2014) is SIZE $=\log$ (Total Asset).

7. Profitability is the company's ability to generate profits to increase the company's shareholder value (Rusdianto, 2013), with the formula:

$$
\text { ROA }=\frac{\text { Pretax Income }}{\text { Total Asset }}
$$

\subsection{Data Analysis}

To test the regression of moderating variable, this study uses an interaction test. Liana (2009) states that interaction testing or often called Moderated Regression Analysis (MRA) is a special application of multiple linear regression. The data processing of this study uses SPSS 18 software, with a research model:

$\mathrm{ARL}=\alpha+\beta 1 \mathrm{EDK}+\beta 2 \mathrm{EKA}+\beta 3 \mathrm{KA}+\beta 4 \mathrm{SIZE}+\beta 5 \mathrm{PROFIT}+\beta 6 \mathrm{EDK} * \mathrm{KH}+\beta 7 \mathrm{EKA} * \mathrm{KH}+\beta 8 \mathrm{SIZE}+\beta 9 \mathrm{PROFIT}+\mathrm{e}$ 
Note:

$\mathrm{ARL}=$ Audit Report Lag

$\mathrm{EDK}=$ Board of Commissioners Effectiveness

$\mathrm{EKA}=$ Audit Committee Effectiveness

$\mathrm{KA}=$ Audit Quality

$\mathrm{KH}=$ Law Compliance

$\mathrm{SIZE}=$ Company Size

PROFIT $=$ Profitability

$\mathrm{e}=$ Errors

\section{Results}

\subsection{Normality Test}

The results of normality testing with the Kolmogorov Smirnov non-parametric statistical test show that the significant value is still below 0.05 . This means that residual data is not normally distributed. Data that is not normally distributed can be transformed to be normal (Ghozali, 2013). In this study, researchers have tried to transform data but the results after the transformation are still not normally distributed. Another way for residual data to be normally distributed is to discard outlier data (as many as 3 companies). The result is shown in Table 1.

Table 1. Normality test

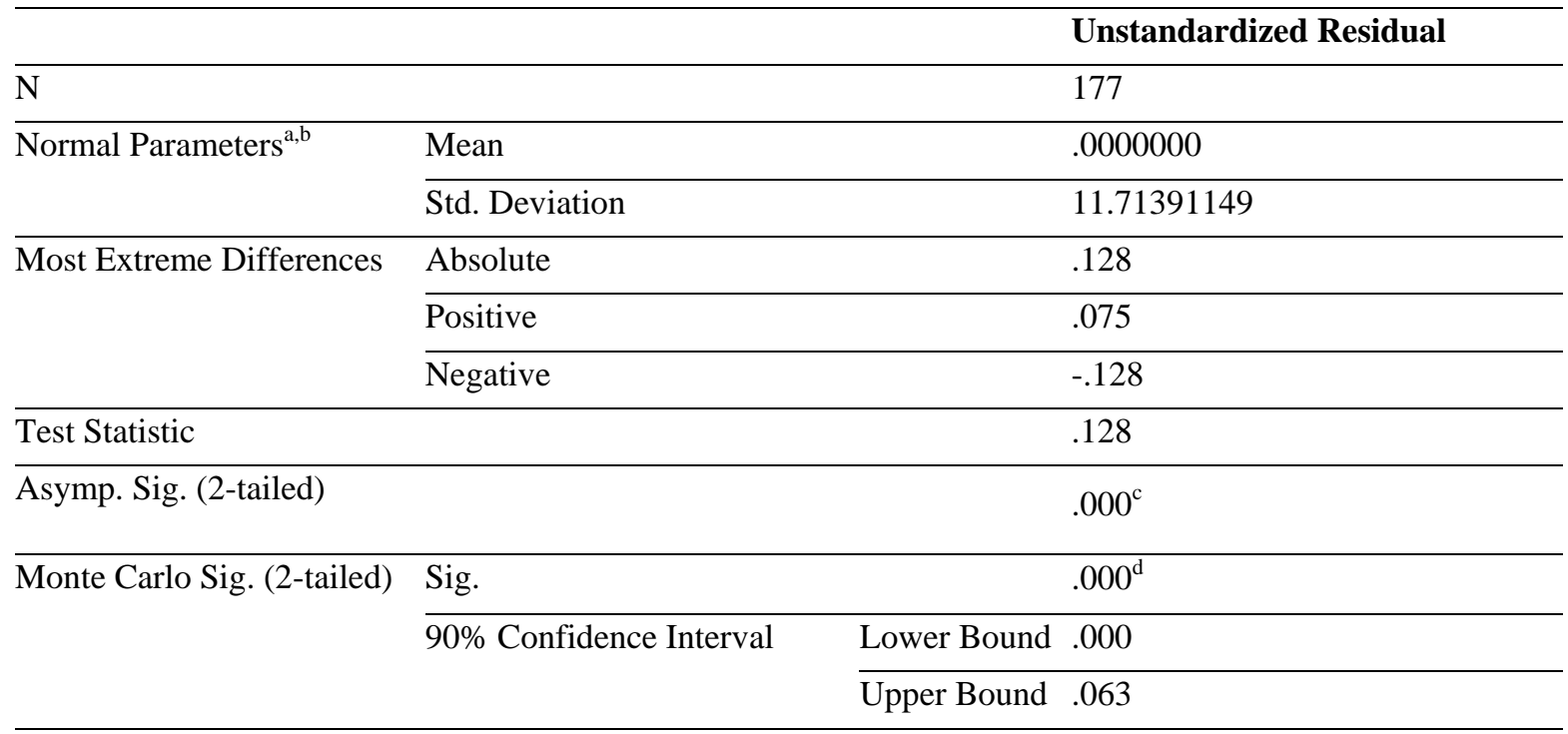

a. Test distribution is Normal.

\subsection{Hypotheses Testing}

The coefficient of determination is used to measure how far the ability of the model in explaining the variation of the independent variable to the dependent. This study uses the adj R2 value because it is able to overcome the bias towards the number of independent variables included in the regression model (Ghozali, 2013). The results of the coefficient of determination can be seen in Table 2 .

Table 2. Determinant coefficient testing

\begin{tabular}{lll}
\hline R Square & Adjusted R Square & Std. Error of the Estimate \\
\hline .149 & .125 & 11.884 \\
\hline
\end{tabular}


Based on Table 2, the coefficient of determination shows the adjusted R2 value is 0.125 . This means that audit report lag of $12.5 \%$ can be explained by board of commissioners effectiveness, audit committee effectiveness, and industry specialist auditor. While $87.5 \%$ audit report lag is explained by other variables that are not investigated in this study.

4.3 F-Test

F-test is conducted to evaluate the suitability of the research model. The results of the F-test can be seen in Table 3 .

Table 3. F-Test

\begin{tabular}{lllllll}
\hline Model & & Sum of Squares & Df & Mean Square & F & Sig. \\
\hline 1 & Regression & 4242.281 & 5 & 848.456 & 6.008 & $.000^{\mathrm{b}}$ \\
\cline { 2 - 7 } & Residual & 24149.967 & 171 & 141.228 & & \\
\cline { 2 - 6 } & Total & 28392.249 & 176 & & & \\
\end{tabular}

a. Dependent Variable: ARL

b. Predictors: (Constant), ROA, EFEK_KA, EFEK_DK, LN_TA, AISPE

In the F-Test, the hypothesis is tested by comparing $\mathrm{F}$ count with $\mathrm{F}$ table, If $\mathrm{F}$ count $>\mathrm{F}$ table, the hypothesis is accepted. In this study, the calculated $F$ value is 6.008 and $F$ table is 2.27 . This means that the model of this study is fit and can be used to predict audit report lag.

4.4 T-Test

T-test is used to determine whether or not there is an effect of each the independent on dependent variable. This is done by comparing $\mathrm{T}$ count with $\mathrm{T}$ table.

Table 4. T-Test

\begin{tabular}{llllll}
\hline \multirow{2}{*}{ Model } & \multicolumn{2}{l}{ Unstandardized Coefficients } & \multicolumn{2}{l}{$\begin{array}{l}\text { Standardized } \\
\text { Coefficients }\end{array}$} & \\
\cline { 2 - 4 } & $\mathbf{B}$ & Std. Error & Beta & $\mathbf{t}$ & Sig. \\
\hline (Constant) & 76.923 & 26.868 & & 2.863 & .005 \\
\hline EFEK_DK & 4.258 & 12.879 & .024 & .331 & .741 \\
\hline EFEK_KA & 11.155 & 13.930 & .060 & .801 & .424 \\
\hline AISPE & -9.559 & 2.409 & -.353 & -3.968 & .000 \\
\hline LN_TA & -.358 & .666 & -.047 & -.538 & .592 \\
\hline ROA & -4.061 & 7.389 & -.040 & -.550 & .583 \\
\hline
\end{tabular}

a. Dependent Variable: ARL

Table 5. Moderating effect

\begin{tabular}{|c|c|c|c|c|c|}
\hline \multirow{2}{*}{ Moderating Effect } & \multicolumn{2}{|c|}{ Unstandardized Coefficients } & \multicolumn{2}{|c|}{$\begin{array}{l}\text { Standardized } \\
\text { Coefficients }\end{array}$} & \multirow[b]{2}{*}{ Sig. } \\
\hline & $\overline{\mathbf{B}}$ & Std. Error & Beta & $\mathbf{t}$ & \\
\hline (Constant) & 109.416 & 10.979 & & 9.966 & .000 \\
\hline MODEDKKH & -14.638 & 6.068 & -.187 & -2.412 & .017 \\
\hline MODEKAKH & -6.742 & 5.474 & -.096 & -1.232 & .220 \\
\hline
\end{tabular}




\section{Discussion}

\subsection{Board of Commissioners Effectiveness and Audit Report Lag}

Based on the results of data processing in Table 4 shows that board of commissioners effectiveness does not affect audit report lag with a significance level of 0.741 , where the significance level is greater than 0.05 . The $T$ value of board of commissioners effectiveness is 0.331 while the $\mathrm{T}$ table is 1.653 . The value of $\mathrm{T}$ count $>\mathrm{T}$ table. Therefore, hypothesis 1 is rejected. This indicates that the increasing proportion of board of commissioners does not increase supervision of the company. The greater the number of members of the board of commissioners will cause difficulties when coordinating between members. The results of this study contradict to the study of Hassan (2016), Swami and Latrini (2013) proved that fraudulent actions in financial statements and information hiding activities carried out by company management will be reduced if there is independent supervisory board supervision. Supervision of independent commissioners is needed to improve quality of financial statements, so that audit work can be reduced.

\subsection{Audit Committee Effectiveness and Audit Report Lag}

Based on the results of data processing shows that audit committee effectiveness does not affect audit report lag with a significance level of 0.424 where the significance level is greater than 0.05 . The $T$ value of audit committee effectiveness is 0.801 while the $\mathrm{T}$ table is 1.653 . The value of $\mathrm{T}$ is calculated $>\mathrm{T}$ table. Thus, Hypothesis 2 is rejected. The existence of audit committee members in the company is limited to fulfilling the existing regulations so that it has not been effective to carry out its role in overseeing the company's management performance.

The results of this study are in line with the research of Lailah (2016) states that audit committees have no effect on audit report lag. This is related to the competence of the audit committee and it is not enough to provide a significant role in financial reporting. To gain an understanding of the company's operating activities, one of the requirements of the audit committee members is to have competence in finance and accounting.

\subsection{Audit Quality and Audit Report Lag}

Based on the results of data processing shows that audit quality proxied by using industry specialist auditors has a significant effect on audit report lag with a significance level of 0.00 , where the significance level is smaller than 0.05 . The $\mathrm{T}$ value calculated audit quality is -3.968 while the $\mathrm{T}$ table is 1.653 . $\mathrm{T}$ count $<\mathrm{T}$ table. Thus, hypothesis 3 is accepted. Competence and auditor's understanding of the client industry and effective audit process are supporting elements in accelerating the publication of the company's financial statements.

This study is in line with the research of Ahsan and Bhuiyan (2010), Habib et al. (2011) that auditors of industry specialization significantly influence audit report lag. Companies audited by industry specialist auditors produce audit report lag that is faster than companies audited by auditors who are not specialists industry. Industry specialist auditors have a better understanding and knowledge than non-industry specialist auditors.

\subsection{Law Compliance and Board of Commissioners on Audit Report Lag}

Based on the results of data processing shows that law compliance improves the relationship between board of commissioners effectiveness and audit report lag with a significance level of 0.017 where the significance level is smaller than 0.05 . The value of $\mathrm{T}$ count is -2.412 while the $\mathrm{T}$ table is 1.653 . $\mathrm{T}$ count $<\mathrm{T}$ table. Thus, hypothesis 4 is accepted. Companies that adhere to existing regulations will try their best to comply with these regulations. The impact that can be caused if the company does not comply with regulations is a very important factor because the company does not want its reputation to be destroyed just because it is too late to produce financial statements. The rules of the financial services authority are very clear when a company is late in publishing financial statements because fines are unavoidable.

The results of this study are in line with the study of Lailah (2016) that the relationship between board of commissioners and audit report lag is significantly positive. This means that more board members will extend the audit report lag. The relationship is weakened by law compliance, where board of commissioners will extend the audit report lag but can be reduced by law compliance.

\subsection{Law Compliance and Audit Committee Effectiveness on Audit Report Lag}

Based on the results of data processing shows that law compliance cannot improve the relationship between board of commissioners effectiveness and audit report lag with a significance level of 0.220 where the significance level is greater than 0.05 . The $\mathrm{T}$ value is -1.232 while the $\mathrm{T}$ table is 1.653 . $\mathrm{T}$ count $<\mathrm{T}$ table. Thus, hypothesis 5 is rejected. The company's understanding of regulations issued by financial service authorities regarding the deadline for submitting audited financial statements has not enough impact on accelerating audit report lag. If the company suffers a loss in its business operations, the company will choose to delay publishing its financial statements. The company does not want 
investors to know the losses experienced by the company, because it will affect the investment invested in the company. The threat of fines sanctions is not considered by the company. The existence of audit committee within the company is limited to fulfilling existing regulations so that it cannot accelerate audit report lag. The results of the study are in line with the study of Lailah (2016) that law compliance cannot improve the relationship between independent audit committee and audit report lag. This means that the higher the size of independent audit committee and law compliance does not affect the shorter the audit report lag in the company.

\subsection{Profitability and Audit Report Lag}

The test results in Table 5 show that ROA does not affect audit report lag. The greater ROA gives an indication of the higher the company in generating profits. The test results show that the value of ROA does not affect the speed of generating audit report lag in the company. The results of this study contradict the research conducted by Lailah (2016) which states that ROA has a significant effect on audit report lag.

\subsection{Company Size and Audit Report Lag}

The test results show that the size of the proxy company with large total assets does not affect the company can result in an increasingly rapid audit report lag. The results of this study contradict the research conducted by Hassan (2016), Laila (2016) which states that firm size has a significant effect on audit report lag.

\section{Conclusion}

The results of this study conclude that:

1. Board of commissioners effectiveness does not affect audit report lag. The greater the number of board of commissioners, it turns out can not increase supervision of the company.

2. Audit committee effectiveness does not affect audit report lag. The existence of audit committee members in the company is limited to fulfilling the existing regulations so that it has not been effective to carry out its role in overseeing the company's management performance.

3. Audit quality that is proxied by using industry specialist auditors influences audit report lag. Companies audited by industry specialist auditors can produce a faster audit report lag.

4. Law compliance can improve the relationship between board of commissioners effectiveness and audit report lag.

\subsection{Limitation and Suggestion}

The limitation and suggestion of this study are as follows:

1. The evaluation of board of commissioners effectiveness and audit committee through scoring is highly dependent on disclosures presented by company in the annual report. The company gets a score of 1 (poor) if there is no information about the criteria in the checklist. This kind of assessment can be supposed to be subjective because giving a poor score is not due to the performance ineffectiveness of board commissioners and audit committee.

2. Future research is recommended to use all companies listed on the Indonesia Stock Exchange so that the results can be more generalized.

\section{References}

Ancella, H. (2009). Pengaruh Efektifitas Dewan Komisaris dan Komite Audit, Kepemilikan oleh Keluarga dan Peran Monitoring Bank terhadap Kandungan Informasi Laba. Disertasi S3 Program Ilmu Akuntansi. Universitas Indonesia.

DeAngelo, L. E. (1981). Auditor Size and auditor Quality. Journal of Accounting and Economics, 3, 183-199. https://doi.org/10.1016/0165-4101(81)90002-1

Deutsch, Y. (2005). The impact of board composition on firms' critical decisions: A meta-analytic review. Journal of Management, 31(3), 424-444. https://doi.org/10.1177/0149206304272185

Deutsch, Y., Keil, T., \& Laamanen, T. (2011). A dual agency view of board compensation: The joint effects of outside director and CEO stock options on firm risk. Strategic Management Journal, 32(2), 212-227. https://doi.org/10.1002/smj.876

Fama, E. F. (1980). Agency problems and the theory of the firm. Journal of Political Economy, 88(2), 288-307. https://doi.org/10.1086/260866

Ghozali, I. (2013). Aplikasi Analisis Multivariate Dengan Program IBM SPSS 21 Semarang: Badan Penerbit 
Universitas Dipenogoro.

Habib, A., \& Bhuiyan, M. B. U. (2011). Audit firm industry specialization and the audit report lag. Journal of International Accounting, Auditing and Taxation, 20(1), 32-44. https://doi.org/10.1016/j.intaccaudtax.2010.12.004

Handayani, Y. (2016). Pengaruh Dewan Komisaris Independen, Auditor Tenure, Auditor Spesialisasi Industry terhadap Audit Report Lag. Jurnal Riset Akuntansi Terpadu, 9(2), 149-288. https://doi.org/10.35448/jrat.v9i2.4312

Hassan, Y. M. (2016). Determinants of audit report lag: evidence from Palestine. Journal of Accounting in Emerging Economies, 6(1), 13-32. https://doi.org/10.1108/JAEE-05-2013-0024

Hersugondo, \& Udin. (2019). Corporate governance and corporate value: The mediating role of investment effectiveness base on human capital. Quality-Access to Success, 20(171), 56-61.

Herusetya, A. (2009). Efektifitas pelaksanaan corporate governance dan Audit eksternal-auditor dengan spesialisasi Industri dalam menghambat Manajemen laba. JAAI Volume, 13(2), 167-188.

Ikatan Akuntan Indonesia. (2001). Standar Profesional Akuntan Publik. Penerbit Salemba Empat. Jakarta.

Ikatan Akuntan Indonesia. (2014). Standar Akuntansi Keuangan. Jakarta: Ikatan Akuntan Indonesia

Jensen, M. C., \& Meckling, W. H. (1976). Theory of the Firm: Managerial Behavior, Agency Cost and Ownership Structure: Journal of Financial Economic, 3, 305-360. https://doi.org/10.1016/0304-405X(76)90026-X

Khajar, I., Hersugondo, H., \& Udin, U. (2018). Antecedents and Outcomes of Corporate Governance: Evidence from Indonesia. European Research Studies Journal, 21(4), 480-492.

Lailah, F. (2016). Ketaatan Hukum Mampukah Memoderasi Hubungan Good Corporate Governance terhadap Audit Report Lag. Simposium Nasional Akuntansi XIX, Lampung.

Naimi, M., et al. (2010). Corporate Governance and Audit Report Lag in Malaysia. Asian Academy of Management Journal of Accounting and Finance, 6, 57-84.

Nurlis. (2014). Pengaruh Firm Size, Jenis Industri, Pertumbuhan Perusahaan, Earning Per Share, Arus Kas dan Leverage terhadap Audit Delay. Jurnal Ilmu Ekonomi dan Sosial, 3(1), 107-117.

Peraturan Otoritas Jasa Keuangan. (n.d.). Retrieved from www.ojk.go.id

Rustiarini, N. W., \& Sugiarti, N. W. M. (2013). Pengaruh karakteristik auditor, opini audit, auditor tenure, pergantian auditor pada audit delay. Jurnal Ilmiah Akuntansi dan Humanika, 2(2).

Swami, N. P. D., \& Latrini, M. Y. (2013). Pengaruh karakteristik corporate governance terhadap audit report lag. E-Jurnal Akuntansi Universitas Udayana, 4(3), 530-549.

Wijaya, A. T. (2012). Pengaruh Karakteristik Komite Audit terhadap Audit Report Lag. FakultasEkonomi. Universitas Diponegoro. Semarang. 